
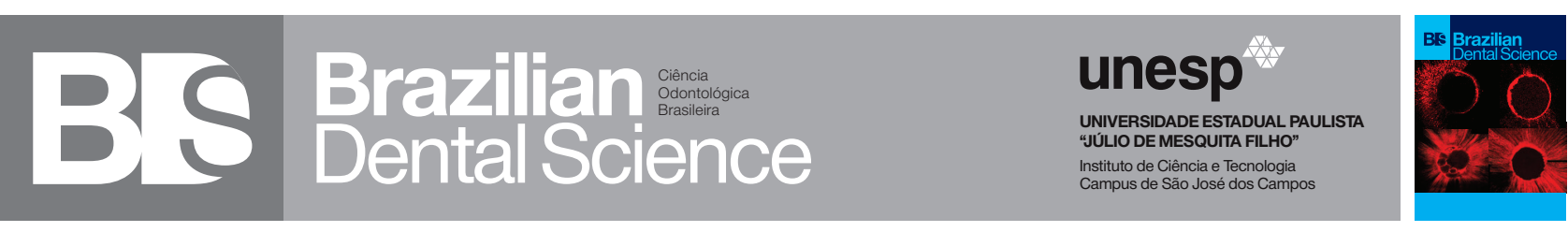

\title{
Effect of Finish Line Design and Cement Space Thickness on the Marginal Accuracy of Monolithic Zirconia Crowns
}

Efeito do desenho da linha de término e da espessura do espaço de cimento na precisão marginal de coroas monolíticas de zircônia

Mohammed F. EL-DAMATY ${ }^{1}$, Mohammed H. ABDEL-AZIZ ${ }^{1}$, Ahmed M.Y. EL-KOUEDI ${ }^{1}$ Tamer A. HAMZA $^{1}$

1 - Crown and Bridge Department - Faculty of Dental Medicine - Al-Azhar University - Cairo - Egypt.

\begin{abstract}
Objective: The purpose of this study was to evaluate the effect of finish line design and cement space thickness on the marginal accuracy of monolithic zirconia crowns. Materials and methods: Thirty crowns were fabricated from translucent zirconia (inCoris TZI) using Cerec in-Lab system and divided into three main groups (10 each) according to the finish line type of the die (knife-edge, chamfer, and shoulder). Every group was divided into two subgroups (5 each) according to cement space thickness (20 and50 $\mu \mathrm{m}$ ). Optical impressions were taken for the dies using the Cerec scanner and cement space was set twice for every finish line design; 20 and 50 $\mu \mathrm{m}$. The completed crowns were cemented to the dies and the marginal gap was evaluated. The collected data was statistically analyzed using Mann-Whitney U test and Kruskal-Wallis test and the significance level was set at $\mathrm{P} \leq$ 0.05. Results: Regarding the marginal gap; there was no statistically significant difference between different finish line designs or between different cement space thicknesses. Conclusion: Neither finish line design nor cement space thickness has an effect on the marginal gap of inCoris TZI crowns.
\end{abstract}

\section{KEYWORDS}

Cement space; Finish line; Marginal fit; Monolithic zirconia.

\section{RESUMO}

Declaração do problema: A necessidade de um método minimamente invasivo de preparação de coroa única é inevitável, principalmente com dentes enfraquecidos e com alta probabilidade de irritação pulpar. Portanto, é necessária uma restauração durável e adaptada, com preparação menos invasiva da linha de término. Objetivo: O objetivo deste estudo foi avaliar o efeito do design da linha de término e da espessura do espaço de cimento na precisão marginal das coroas monolíticas de zircônia. Material e Métodos: Trinta coroas foram fabricadas a partir de zircônia translúcida (inCoris TZI) usando o sistema Cerec em laboratório, e divididas em três grupos principais (n = 10), de acordo com o tipo de linha de término da matriz (lâmina, chanfro e ombro). Cada grupo foi dividido em dois subgrupos (5 cada), de acordo com a espessura do espaço do cimento (20 e $50 \mu \mathrm{m})$. Impressões ópticas foram obtidas para as matrizes usando o scanner Cerec e o espaço de cimento foi definido duas vezes para cada projeto de linha de chegada: $20 \mathrm{e}$ $50 \mu \mathrm{m}$. As coroas confeccionadas foram cimentadas nos moldes e a diferença marginal foi avaliada. Os dados coletados foram analisados estatisticamente pelo teste U de Mann-Whitney e Kruskal-Wallis e o nível de significância foi estabelecido em P $\leq$ 0,05. Resultados: Em relação ao gap marginal não houve diferença estatisticamente significante entre diferentes projetos de linha de acabamento ou entre diferentes espessuras de espaço de cimento. Conclusão: nem o design da linha de término, nem a espessura do espaço de cimento afetam a folga marginal das coroas inCoris TZI.

\section{PALAVRAS-CHAVE}

Espaço de cimento; Linha de término; Ajuste marginal; Zircônia monolítica. 


\section{INTRODUCTION}

$\mathrm{T}$ he demand for traditional porcelain fused to metal (PFM) restorations is decreasing due to the introduction of reliable ceramic restorations. One of these ceramics is zirconiabased restorations which consist of a zirconia core that veneered for optimal esthetic properties $[1,2]$.

Unfortunately, the zirconia core-veneer interface is the weakest features of these restorations, so that ceramic veneer chipping or cracking is possible [3]. Several factors may affect veneer cracking such as; differences in the coefficient of thermal expansion between core and ceramic veneer, firing shrinkage of ceramic, flaws on veneering, and poor wettability of veneering on the core [4].

With the introduction of monolithic (fully contoured) zirconia restoration, the problem of delamination of the veneering ceramic from zirconia core does not exist anymore, as the anatomically and full contoured restoration can be fabricated and milled from zirconia blocks without the need for veneering [5].

These monolithic zirconia restorations had reduced translucency which affect overall esthetic properties. This has been overcome by decreasing the amount of the light scattering sources as alumina particles without significantly effecting its mechanical properties. After milling of monolithic zirconia restoration from a presintered block, adequate coloring liquid is applied, dried, and finally sintered at temperature (1350$1600{ }^{\circ} \mathrm{C}$ ) to enhance its esthetics [6].

Marginal fit is considered one of the most important criteria used in the evaluation of fixed dental prostheses (FDPs). Good marginal fit is one of the most significant prerequisites for the long-term success of all-ceramic restorations [7]. The larger the marginal discrepancy, the more the luting material is exposed to the oral environment and is also associated with a higher plaque index and loss of attachment [8,9]. Furthermore, if the cement seal fails and allows bacterial percolation, this could be one of the causes of pulpal inflammation, secondary caries, and eventually pulpal death and necrosis [10].

Marginal fit has been evaluated for ceramic crowns by several studies, which show a higher degree of variation for different ceramic systems. Most investigators continue to use the criteria established by McLean and Von Fraunhofer in 1971 [11], where they concluded after a 5-year clinical study of 1000 restorations, that $120 \mu \mathrm{m}$ was the maximum acceptable marginal opening (ranging from 100 to $120 \mu \mathrm{m}$ ).

Wolfart et al investigated the in vivo marginal discrepancy of a heat-pressed lithiumdisilicate glass-ceramic FDPs and reported values between $89 \mu \mathrm{m}$ and $130 \mu \mathrm{m}$ [12]. Riccitiello et al. reported absolute marginal opening of 65 ( \pm 23 ) for CAD/CAM zirconia, 69 ( \pm 41 ) for CAD/ CAM lithium disilicate, and $85( \pm 26)$ for heat pressed lithium disilicate [13]. Grenade et al also demonstrated the mean marginal gap width of a single tooth zirconia coping of $51 \mu \mathrm{m}$ for the Procera CAD/CAM system [14], while Cho et al demonstrated a mean marginal opening of 27.5 $\mu \mathrm{m}$ for IPS e.max Press [15]. In a recent study by Ahmed et al, they reported that the marginal discrepancy for monolithic zirconia crowns was seen to be between $11 \mu \mathrm{m}$ and $52 \mu \mathrm{m}$ [16].

Theoretically speaking; preserving a maximum amount of sound tooth structure during tooth preparation for fixed abutments, as it is done in vertical preparations (knife-edge or feather-edge), might be a less invasive alternative to a horizontal margins (shoulder or chamfer). This would be true not only for periodontally treated teeth, but also in other clinical conditions such as endodontically treated teeth, vital teeth in young individuals, and teeth affected by caries at the cervical third of the clinical crown [17].

From a periodontal point of view, the suggested advantages of horizontal margins over 
vertical ones have not been clinically demonstrated [18]. However, histological evidence shows no difference in periodontal health among different patterns of margin designs [19]. Moreover, the presence of crown margins in teeth restored with knife edge margins showed no more influence over gingival conditions than in natural teeth [20].

Comlekoglu et al stated that; the marginal openings with the feather-edge finish line were significantly lower than those of the chamfer, shoulder and light chamfer finish line types [21], and Poggio et al concluded that, for zirconia crowns, knife-edge margins allow clinical performance similar to that reported with other margin designs but with less invasive preparations [22].

The precision of marginal fit is paramount in dental restoration whether to satisfy biologic, physical or cosmetic requirements. Factors that affect marginal fit include finish line design, convergence angle, cement space thickness, material and method of construction. Different finish line designs could have a great impact on this precision and eventually affect the overall success of the final restoration. However, the results on the effect of finish line design on the marginal discrepancies are controversial in the dental literature.

As seen in studies by Hamaguchi et al. [23] and Limkangwalmongkol et al. [24] found that the finish line design has no significant effect on the marginal gap of single-tooth crowns. On the other hand, some investigators advocated the use of shoulder finish line which resisted distortion and had less marginal discrepancy than the chamfer finish line $[25,26]$. While other investigators found improved marginal fit with chamfer margins compared to shoulders [27,28], and others found that the best marginal seal is obtained by knife-edge margins [21,29].

Concerning the cement space thickness; Nakamura et al. [30] evaluated the marginal and internal fit of all ceramic crowns fabricated by the Decsy CAD/CAM system, with two occlusal convergence angles $\left(4^{\circ}\right.$ and $12^{\circ}$ ), and two cement space settings specified on the computer (15 $\mu \mathrm{m}$ and $55 \mu \mathrm{m}$ ). They found that neither the internal gap nor marginal gap was affected by the occlusal convergence angle of the abutment, but internal gap was significantly smaller when the cement space was set at $15 \mu \mathrm{m}$.

Iwai et al. [31] found that the different cement spaces did not have any significant influence on the marginal discrepancy of $12^{\circ}$ convergence angle group after evaluating the influence of total convergence angles $(6,12$, and 20 degrees) and cement spaces (10, 30, 60 $\mu \mathrm{m})$ on the internal and marginal adaptation of posterior zirconia copings.

As cement space thickness can be controlled by computer software, it was found that the newer version gives better adaptation, as described by Shim et al. [32] when they compared the effect of Cerec software versions (3.8 and 4.2). They recommend the software version 4.2 for the fabrication of well-fitting crown restorations, and for the appropriate regulation of the spacer parameter. Also, they suggested using $80 \mu \mathrm{m}$ spacer setting for the version 4.2 even though it produced a larger gap than $40 \mu \mathrm{m}$ because it has shown a good repeatability as they claimed.

Therefore, the hypothesis of this study was that the finish line type as well as the cement space thickness will influence the marginal accuracy of the Cerec fabricated monolithic zirconia crowns.

\section{MATERIAL AND METHODS}

Three stainless steel dies were fabricated by a milling machine to simulate preparation of a maxillary first premolar. Each die was machine-milled with $4.5 \mathrm{~mm}$ height, $12^{\circ}$ total occlusal convergence angle, and flat occlusal surface [33]. An occlusal bevel was prepared at the occluso-axial line angle on one side of each die for exact repositioning of the crowns during 
measurements. Each die had a different finish line: knife-edge $(0.2 \mathrm{~mm})$, chamfer $(0.5 \mathrm{~mm})$, and rounded-shoulder $(1.0 \mathrm{~mm})$ (Figure 1$)$. Four equidistant marks were engraved on each die 1.0 $\mathrm{mm}$ below the margin with a high-speed round diamond rotary cutting instrument to orient the microscope during marginal gap measurements.

A total of 30 monolithic inCoris TZI crowns (Sirona, Bensheim, Germany) were divided into three main groups according to the finish line design: Group K: Knife-edge finish line (10 crowns), Group C: Chamfer finish line (10 crowns), and Group S: radial Shoulder finish line (10 crowns). Every group was divided into two subgroups according to cement space settings: Subgroup 20: Cement space was set to $20 \mu \mathrm{m}$, and Subgroup 50: Cement space was set to 50 $\mu \mathrm{m}$.

All crowns were fabricated from inCoris TZI blocks (Sirona, Bensheim, Germany) size 55/19 using Cerec inLab system (Sirona Dental Systems GmbH, D-64625 Bensheim, Germany) according to the manufacture instruction. The metal dies were sprayed with Cerec Optispray (Sirona Dental Systems) and optical impressions were taken for the metal dies by using inEos Blue scanner (Sirona Dental Systems GmbH).

Automatic margin detection was done for the virtual die, insertion axis was determined, and restoration parameters were set. The only variable in this study was the spacer thickness which was set twice (20 $\mu \mathrm{m}$ and $50 \mu \mathrm{m})$ for every finish line design.

The milled crownswere dried at temperature of $150^{\circ} \mathrm{C}$ for $10 \mathrm{~min}$ then dyed with A2 shade by using inCoris TZI coloring liquid (Sirona Dental Systems GmbH, D-64625 Bensheim, Germany) before sintering. The Sirona inFire HTC furnace (Sirona Dental Systems GmbH, D-64625 Bensheim, Germany) was used for sintering the inCoris TZI crowns, as recommended by manufacturer. The sintered crowns where then checked on their corresponding dies and given a serial number according to each group.

With the aid of a specially designed cementing device (of $4 \mathrm{Kg}$ weight), the sintered crowns were cemented conventionally with glass ionomer cement (Ketac Cem, 3M ESPE, Seefeld, Germany) to their corresponding metal dies for $10 \mathrm{~min}$. The vertical marginal gap was evaluated by using a USB Digital microscope (Scope Capture Digital Microscope, Guangdong, China) at magnification X100.

The vertical marginal gap between the cervical margin of the crown and the outer end of the finish line was measured at the four predetermined landmarks. Measurement at each point was repeated three times. Then the obtained data were collected and tabulated using Microsoft Excel.

The mean vertical marginal gap for each specimen was calculated and then subjected to statistical analysis which was performed with a computer program (SPSS 20, SPSS Inc., IBM Corporation, NY, USA) for Windows. Numerical data were explored for normality by checking the distribution of data and using tests of normality (Kolmogorov-Smirnov and Shapiro-Wilk tests). The significance level was set at $\mathrm{P} \leq 0.05$.

\section{RESULTS}

Marginal gap distance data showed nonparametric distribution. Data were presented as mean, standard deviation (SD), median, minimum, maximum and 95\% Confidence Interval (95\% CI) for the mean values.

Mann-Whitney U test was used to compare between the two cement spaces. Kruskal-Wallis test was used to compare between the three finish line designs.

Post hoc-power analysis value was 0.956 . The significance level was set at $\mathrm{P} \leq 0.05$. Descriptive statistics of marginal gap distance values are presented in Table I. 
Table I - Descriptive statistics of marginal gap distance values.

\begin{tabular}{|c|c|c|c|c|c|c|c|c|}
\hline \multirow{2}{*}{$\begin{array}{l}\text { Finish line } \\
\text { design }\end{array}$} & \multirow{2}{*}{ Cement space } & \multirow{2}{*}{ Mean $(\mu \mathrm{m})$} & \multirow{2}{*}{ SD } & \multirow{2}{*}{ Median $(\mu \mathrm{m})$} & \multirow{2}{*}{ Minimum $(\mu \mathrm{m})$} & \multirow{2}{*}{ Maximum $(\mu \mathrm{m})$} & \multicolumn{2}{|c|}{$95 \%$ Cl } \\
\hline & & & & & & & Lower bound & Upper bound \\
\hline \multirow{2}{*}{ Knife-edge } & $20 \mu \mathrm{m}$ & 42.9 & 13.6 & 36.0 & 28.3 & 59.5 & 26.0 & 59.8 \\
\hline & $50 \mu \mathrm{m}$ & 28.4 & 2.0 & 28.7 & 26.1 & 30.5 & 25.9 & 30.9 \\
\hline \multirow{2}{*}{ Chamfer } & $20 \mu \mathrm{m}$ & 31.1 & 10.9 & 26.2 & 22.2 & 47.5 & 17.5 & 44.7 \\
\hline & $50 \mu \mathrm{m}$ & 34.5 & 6.5 & 31.4 & 27.2 & 42.2 & 26.4 & 42.7 \\
\hline \multirow{2}{*}{ Shoulder } & $20 \mu \mathrm{m}$ & 29.7 & 14.4 & 23.3 & 17.5 & 52.3 & 11.9 & 47.6 \\
\hline & $50 \mu \mathrm{m}$ & 36.2 & 9.3 & 39.2 & 25.2 & 47.8 & 24.7 & 47.7 \\
\hline
\end{tabular}

\section{Comparison between finish line designs:}

There was no statistically significant difference between mean marginal gap distances of the three finish line designs. Table II, Figure 2.

\section{Comparison between cement spaces:}

There was no statistically significant difference between mean marginal gap distances with the two cement spaces. Table II, Figure 2.

Table II - The mean, standard deviation (SD) values, results of Mann-Whitney $U$ test and Kruskal-Wallis test for comparison between marginal gap distances of different interactions:

\begin{tabular}{|cccccc|}
\hline Finish line design & \multicolumn{2}{c}{$\mathbf{2 0} \boldsymbol{\mu m}$} & \multicolumn{2}{c}{$\mathbf{5 0} \boldsymbol{\mu m}$} & $\begin{array}{c}\text { P-value } \\
\text { (Between } \\
\end{array}$ \\
\cline { 2 - 6 } & Mean & SD & Mean & SD & $\begin{array}{c}\text { cement } \\
\text { spaces) }\end{array}$ \\
\hline Knife-edge & 42.9 & 13.6 & 28.4 & 2.0 & 0.056 \\
\hline Chamfer & 31.1 & 10.9 & 34.5 & 6.5 & 0.421 \\
\hline $\begin{array}{c}\text { Shoulder } \\
\text { S-value (Between } \\
\text { finish line designs) }\end{array}$ & 29.7 & 14.4 & 36.2 & 9.3 & 0.310 \\
\hline
\end{tabular}

*: Significant at $\mathrm{P} \leq 0.05$

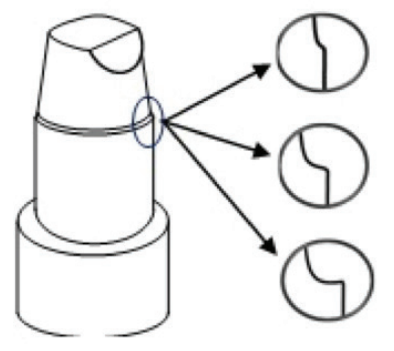

$0.2 \mathrm{~mm}$ Knife-edge

$0.5 \mathrm{~mm}$ Chamfer

$1.0 \mathrm{~mm}$ Rounded Shoulder

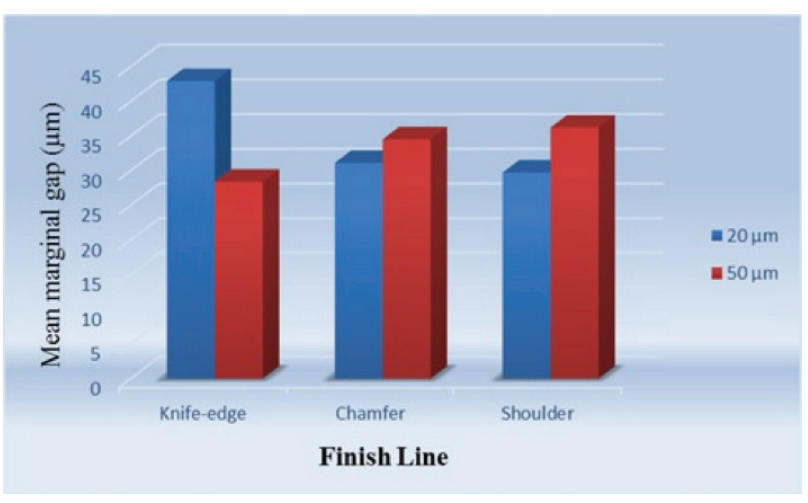

Figure 2 - Bar chart representing mean marginal gap distance of the different interactions of variables.

\section{DISCUSSION}

Zirconia has been used commonly for the fabrication of single restorations to complex full arch restorations, from implant fixtures to orthodontic brackets. Monolithic translucent zirconia used in the present study, was used to overcome the delamination drawback of the conventional zirconia restoration by milling anatomically and fully contoured restoration without need for veneering porcelain [6].

The stainless-steel abutment die used in the present study was similar to that used in several previous studies $[23,33]$. The advantages of the metal die are standardized preparation and lack of die wear during the manufacturing processes and measurement procedures. The metal dies were machinemilled to simulate a preparation of maxillary premolar for full coverage all-ceramic crown with $4.5 \mathrm{~mm}$ height and $12^{\circ}$ total occlusal convergence angle like other studies $[7,33]$, 
as it was found that preparation angle of $12^{\circ}$ achieved the best overall precision of zirconiabased single crowns [34].

The gap measurement was repeated three times for every measured point to increase reliability, and an occlusal bevel was prepared at the occluso-axial line angle in one side of each die for exact repositioning of the crown during the measuring procedures. Four predetermined marks were engraved on each die $1.0 \mathrm{~mm}$ below the margin to orient the microscope during marginal gap measurements.

The ability to directly visualize and measure marginal discrepancies by means of microscope photography provided accuracy and reproducibility. The assessment of marginal fit was performed by using USB digital microscope; all measurements were made by the same operator to avoid errors as much as possible. Direct viewing with external measurements, which was used in this study, has the advantage of not being invasive, cheaper, and less time-consuming than other techniques and reduces the chance of error accumulation that may results from multiple procedures and therefore applicable to clinical practice.

In the present study, the fit of crowns was assessed based on the vertical marginal gap, because this discrepancy is the least liable to correction after crown fabrication, as indicated by Holmes et al. [35]. Horizontal discrepancies, such as crown overhangs, can be adjusted to some degrees intraorally but the vertical marginal gap can only be closed with luting cement, which is prone to dissolution [11]. For this reason, the vertical marginal gap has the most clinical relevance and should be regarded as the most critical in crown margin evaluation [12].

Although there is no standard for marginal gap limit, most investigators continue to use the criteria established by McLean and Von Fraunhofer [11], after a 5-years clinical study of 1000 restorations. They concluded that $120 \mu \mathrm{m}$ was the maximum acceptable marginal opening, and was set as the limit in this study.

Chamfer or shoulder finish lines can be selected for ceramic crowns that bonded to prepared teeth, as the recommended finish line depth has been ranged from 0.5 to1.0 $\mathrm{mm}$. [7]. Recently; knife-edge finish line for zirconia crowns has been introduced as a less invasive preparation design that allows acceptable clinical performance [22].

In the present study; the tested hypothesis was rejected as there was no statistical significant difference found regarding the cement space or the finish line design.

The results of the present study were in agreement with many other studies [23,24]; as they all found that the finish line design has no significant effect on the marginal gap of single-tooth zirconia crowns. On the other hand, some studies advocate the use of shoulder finish line as they found it had less marginal discrepancy [25,26], But other investigators found better marginal fit with chamfer margins compared to shoulders $[27,28]$. Where others found that the best marginal seal is obtained by knife-edge margins [21,29].

Although, the knife-edge finish line resulted in lower marginal opening values in a study of Comlekoglu et al, [21] they recommended shoulder and mini-chamfer in clinical application from biological and technical standpoint, as it triggers the wedging effect at the margin and may provide additional marginal bulk.

However; these recommendation to avoid knife-edge margins is not supported by clinical study of Poggio et al. [22] as they found that knife-edge margins allow clinical performance 
similar to that reported by other margin designs but with less invasive preparations, and also not supported by others $[18,19]$ as the histological evidence showed no difference in periodontal health among different patterns of margin designs. Moreover; knife edge margins showed no more influence over gingival conditions than natural teeth in a sample of periodontal patients [20].

When considering all criteria; the vertical marginal discrepancy values obtained in the present study were all within the clinically acceptable standard limit which was set to 120 $\mu \mathrm{m}$.

The limitation of this study includes; the use of metal die instead of natural teeth and using straight instead of curved finish line (mesio-distally \& bucco-lingually) which might give different results. And only the vertical marginal gap was measured, the horizontal relationship was not calculated. Further studies of different abutment finish line designs could evaluate marginal accuracy for other ceramic systems, and another would explain the effect of finish line curvature with different finish line designs on the marginal accuracy of monolithic ceramic crowns.

\section{CONCLUSION}

Within the limitation of this study; neither finish line design nor cement space thickness have an effect on the marginal gap of inCoris TZI crowns.

\section{Clinical recommendations:}

In the light of the present study; consideration should be given to a minimally invasive preparation designs from a prophylactic point of view with emphasis on conserving tooth structure and preventing preparation trauma.

\section{REFERENCES}

1. Raigrodski AJ. Contemprary materials and technologies for all-ceramic fixed partial dentures: A review of the literature. J Prosthet Dent 2004 Dec; 92(6):557-62. doi: 10.1016/j.prosdent.2004.09.015

2. Nakamura T, Dei N, Kojima T, Wakabayashi k. Marginal and internal fit of Cerec 3 CAD/CAM all ceramic crowns. Int J Prosthodont. 2003 May-Jun; 16(3):244-8. PMID: 12854786

3. Aboushelib MN, de Jager N, Kleverlaan CJ, Feilzer AJ. Effect of loading method on the fracture mechanics of two layered all-ceramic restorative systems. Dent Mater 2007 Aug; 23(8):952-9. doi: 10.1016/j. dental.2006.06.036

4. Aboushelib MN, Kleverlaan CJ, Feilzer AJ. Microtensile bond strength of different components of core veneered all ceramic restorations. Part II: Zirconia veneering ceramics. Dent Mater 2006 Sep; 22(9):857-63. doi: 10.1016/j.dental.2005.11.014

5. Sirona Dental Systems GmbH. Translucent zirconia ceramic blocks for in Lab. Processing instructions: restoration production for crowns and bridges 2013;1_22.

6. Ban S, Suzuki T, Yoshihara K, Sasaki K, Kawai T, Kono H. Effect of coloring on mechanical properties of dental zirconia. J Med Bio Eng 2014; 34(1):24-9. doi: 10.5405/jmbe.1425

7. Goodacre CJ, Campagni WV, Aquilino SA. Tooth preparations for complete crowns: An art form based on scientific principles. J Prosthet Dent 2001 Apr; 85(4):363-76. doi: 10.1067/mpr.2001.114685

8. Beuer F, Aggstaller H, Edelhoff D, Gernet W, Sorensen J. Marginal and internal fits of fixed dental prostheses zirconia retainers. Dent Mater 2009 Jan; 25(1):94-102. doi: 10.1016/j.dental.2008.04.018

9. Beuer F, Aggstaller H, Richter J, Edelhoff D, Gernet W. Influence of preparation angle on marginal and internal fit of CAD/CAM fabricated zirconia crown copings. Quintessence Int. 2009 Mar; 40(3):243-50. PMID: 19417888

10. Goldman M, Laosonthorn P, White RR. Microleakage: full crowns and the dental pulp. JEndod 1992 0ct; 18(10):473-5. doi: 10.1016/S00992399(06)81345-2

11. McLean JW, Von Fraunhofer JA. The estimation of cement film thickness by an in vivo technique. Br Dent J 1971 Aug; 131(3):107-11. doi: 10.1038/ sj.bdj.4802708

12. Wolfart S, Wegner SM, Al-Halabi A, Kern M. Clinical evaluation of marginal fit of a new experimental all-ceramic system before and after cementation. Int J Prosthodont 2003 Nov-Dec; 16(6):587-92. PMID: 14714835

13. Riccitiello F, Amato M, Leone R, Spagnuolo G, Sorrentino R. In vitro Evaluation of the Marginal Fit and Internal Adaptation of Zirconia and Lithium Disilicate Single Crowns: Micro-CT Comparison Between Different Manufacturing Procedures. Open Dent J. 2018 Feb; 22;12:160-72. doi: 10.2174/1874210601812010160

14. Grenade C, Mainjot A, Vanheusden A. Fit of single tooth zirconia copings: comparison between various manufacturing processes. J Prosthet Dent 2011 Apr; 105(4):249-55. doi: 10.1016/S0022-3913(11)60040-1

15. Cho SH, Nagy WW, Goodman JT, Solomon E, Koike M. The effect of multiple firings on the marginal integrity of pressable ceramic single crowns. J Prosthet Dent 2012 Jan; 107(1):17-23. doi: 10.1016/S0022-3913(12)60011-0 
16. Ahmed WM, Abdallah MN, McCullagh AP, Wyatt CCL, Troczynski T, Carvalho RM. Marginal Discrepancies of Monolithic Zirconia Crowns: The Influence of Preparation Designs and Sintering Techniques. J Prosthodont 2019 Mar; 28(3):288-98. doi: 10.1111/jopr.13021

17. Schmitt J, Wichmann M, Holst S, Reich S. Restoring severely compromised anterior teeth with zirconia crowns and featheredged margin preparations: a 3-year follow-up of a prospective clinical trial. Int J Prosthodont 2010 Mar-Apr; 23(2):107-9. PMID: 20305846

18. Lang NP.Periodontal considerations in prosthetic dentistry. Periodontology 2000 1995 0ct; 9:118-31. doi: 10.1111//.1600-0757.1995.tb00060.x

19. Carnevale G, Sterrantino SF, Di Febo G. Soft and hard tissue wound healing following tooth preparation to the alveolar crest. Int J Periodontics Restorative Dent 1983;3(6):36-53. PMID: 6584413

20. Carnevale G, Di Febo G, Fuzzi M. A retrospective analysis of the perioprosthetic aspect of teeth re-prepared during periodontal surgery. J Clin Periodontal 1990 May; 17(5):313-6. doi: 10.1111/.j.1600-051x.1990.tb01095.x

21. Comlekoglu M, Dundar M, Ozcan M, Gungor M, Gokce B, Artunc C. Influence of cervical finish line type on the marginal adaptation of zirconia ceramic crowns. Oper Dent 2009 Sep-0ct; 34(5):586-92. doi:10.2341/08076-L

22. Poggio $\mathrm{CE}$, Dosoli $\mathrm{R}$, Ercoli C. A retrospective analysis of 102 zirconia single crowns with knife-edge margins. J Prosthet Dent 2012 May; 107(5):316-21 doi: 10.1016/S0022-3913(12)60083-3

23. Hamaguchi $\mathrm{H}$, Cacciatore A, Tueller VM. Marginal distortion of the porcelain bonded-to metal complete crown: an SEM study. J Prosthet Dent $1982 \mathrm{Feb}$; 47(2):146-53. doi: 10.1016/0022-3913(82)90178-0

24. Limkangwalmongkol P, Kee E, Chiche G, Blatz M. Comparision of Marginal Fit between All-Porcelain Margin versus Alumina-Supported Margin on Procera Alumina Crowns. J Prosthodont. 2009 Feb; 18(2):162-6. doi: 10.1111/j.1532-849X.2008.00396.X

25. Shillingburg $\mathrm{HT} \mathrm{Jr}$, Hobo S, Fisher DW. Preparation design and margin distortion in porcelain-fused-to-metal restorations. J Prosthet Dent. 1973 Mar; 29(3):276-84. doi: 10.1016/0022-3913(73)90007-3

26. Faucher R, Nicholls JI. Distortion related to margin design in porcelain fused-to-metal restorations. J Prosthet Dent. 1980 Feb; 43(2):149-55. doi: 10.1016/0022-3913(80)90178-x
27. Pera P, Gilodi S, Bassi F, Carossa S. In vitro marginal adaptation of alumina porcelain ceramic crowns. J Prosthet Dent. 1994 Dec; 72(6):585-90. doi: 10.1016/0022-3913(94)90289-5

28. Rahshenas N, Motamedi MHK, Nazari MS, Salari MH, Modaber B. effect of shoulder and deep chamfer finish lines on marginal fitness of electroformed PFM restorations. J Interdiscipl Med Dent Sci. 2014; 2:145. doi:10.4172/2376-032X.1000145

29. Nemane V, Akulwar RS, Meshram S. the effect of various finish line configurations on the marginal seal and occlusal discrepancy of cast full crowns after cementation - An In-vitro Study. J Clin Diagn Res. 2015 Aug; 9(8):18-21. doi: 10.7860/JCDR/2015/12574.6283

30. Nakamura T, Tanaka H, Kinuta S, Akao T, Okamoto K, Wakabayashi K, Yathani $\mathrm{H}$. In vitro study on marginal and internal fit of CAD/CAM all ceramic crowns. Dent Mater J 2005 Sep; 24(3):456-9. doi: 10.4012/ dmj.24.456

31. Iwai T, Komine F, Kobayashi K, Saito OA, Matsumura H. Influence of convergence angle and cement space on adaptation of zirconium dioxide ceramic copings. Acta Odont Scand 2008 Aug; 66(4):214-8. doi: 10.1080/00016350802139833

32. Shim JS, Lee JS, Lee JY, Choi YJ, Shin SW, Ryu JJ. Effect of software version and parameter settings on the marginal and internal adaptation of crowns fabricated with the CAD/CAM system. J Appl Oral Sci 2015 Oct; 23(5):515-22. doi: 10.1590/1678-775720150081

33. Colpani JT, Borba M, Bona AD. Evaluation of marginal and internal fit of ceramic crown copings. Dent Mater 2013 Feb; 29(2):174-80. doi: 10.1016/j. dental.2012.10.012

34. Beuer F, Edelhoff D, Gernet W, Naumann M. Effect of preparation angles on the precision of zirconia crown copings fabricated by CAD/CAM system. Dent Mater J. 2008 Nov; 27(6):814-20. doi: 10.4012/dmi.27.814

35. Holmes JR, Bayne SC, Holland GA, Sulik WD. Considerations in measurements of marginal fit. J Prosthet Dent 1989 0ct; 62(4):405-8. doi: 101016/0022-3913(89)90170-4

\section{Mohammed F. El-Damaty} (Corresponding address)

Faculty of Dental Medicine, Al-Azhar University, Nasr City, Cairo, Egypt. 